\title{
Analisis Hubungan Faktor Internal Dan Eksternal Dengan Kinerja Bidan Desa Dalam Deteksi Dini Dan Penanganan Ibu Hamil Kekurangan Energi Kronik (KEK) di Kabupaten Grobogan Tahun 2015
}

\author{
Rosmala Kurnia Dewi ${ }^{1}$, Sri Achadi Nugraheni ${ }^{2}$, Ayun Sriatmi ${ }^{2}$ \\ 1) Akademi Kebidanan An Nur Purwodadi \\ 2) Fakultas Kesehatan Masyarakat, Universitas Diponegoro, Semarang
}

\section{Title : Analysis Of Internal And External} Factors Related To The Performance Of Midwives In Early Detection And Treatment Of Pregnant Women's Chronic Lack Of Energy (KEK) In Grobogan Regency In The Year Of 2015

\section{Abstrak}

Kejadian KEK merupakan salah satu penyebab AKI dan AKB secara tidak langsung. Jumlah AKI di Kabupaten Grobogan tahun 2011 sebanyak 26 kasus $(114,03 / 100.000 \mathrm{KH})$, tahun 2012 meningkat menjadi 34 kasus (AKI 151,15/100.000 KH), dan tahun 2013 menurun menjadi 22 kasus (AKI 102,03/100.000 KH). Sedangkan AKB tahun 2011 sebesar 194 kasus, terjadi kenaikan pada tahun 2012 sebesar 240 dan kembali turun pada tahun 2013 sebesar 166 kasus. Salah satu penyebab AKB adalah BBLR, karena pada masa kehamilan ibu mengalami KEK. Tujuan penelitian untuk menganalisis faktor internal dan eksternal dengan kinerja bidan desa dalam deteksi dini dan penanganan ibu hamil dan penanganan KEK.

Jenis penelitian adalah observasional analitik dengan pendekatan cross sectional. Cara pengambilan data dengan kuesioner terstruktur. Populasi adalah 243 bidan desa di Puskesmas Kabupaten Grobogan. Jumlah sampel adalah 71 bidan desa yang dipilih secara Stratified Random Sampling. Analisis hubungan dengan uji Chi Square dan multivariat dengan Regresi Logistik.

Hasil penelitian menunjukkan bahwa umur responden 20-35 tahun (76,1\%), masa kerja tergolong baru/ $\leq 6$ tahun $(53,5 \%)$ dan responden pernah melakukan penanganan KEK (81,7\%). Ada hubungan antara fasilitas kesehatan $(\mathrm{p}=0,001)$, dukungan rekan kerja $(\mathrm{p}=0,016)$, dukungan masyarakat $(\mathrm{p}=0,001)$, dukungan pimpinan $(p=0,0001)$ dengan kinerja bidan desa dalam deteksi dini ibu hamil KEK. Faktor yang berpengaruh secara bersama-sama terhadap kinerja adalah fasilitas kesehatan $(p=0,000$; $\operatorname{Exp}(B)=25,395)$, dukungan pimpinan $(p=0,001$; $\operatorname{Exp}(B)=10,278)$.

Disarankan kepada instansi terkait (Puskesmas dan Dinas Kesehatan Kabupaten) memberikan fasilitas kesehatan yang lengkap dan memadai agar meningkatkan kinerja tenaga kesehatan dalam pelayanannya.

Kata kunci : Bidan Desa, Kinerja, Deteksi Dini dan Penanganan Ibu Hamil KEK

Referensi : :14 (1990-2012)

\section{Abstract}

The occurence of $K E K$ is one of the causes of $A K I$ and $A K B$ indirectly. The number of AKI in Grobogan in 2011 reached 26 cases $(114,03 / 100.000 \mathrm{KH})$, and increased to 34 (AKI $151,15 / 100.000 \mathrm{KH})$ in 2012, then decreased to 22 (AKI 102,03/100.000 KH) in 2013. Meanwhile, $A K B$ in 2011 was 194 cases, there was an increase to 240 in 2012 and decreased to 166 in 2013. One of its cause was BBLR, because the mother encountered KEK during the pregnancy. The aim of this research is to analyze the internal and external factors related to the performance of midwives in early detection and treatment of pregnant women and treatment of KEK.

The study of the research is observational analytics by cross sectional approach. The method of data sampling was using structured questionnaires. The population was 243 midwives in public health centers of Grobogan. The number of sample was 71 midwives, selected by Stratified Random Sampling. The analysis of correlation was using Chi Square test and multivariate logistic regression.

The results showed that most respondents was between 20 to 35 years old (76.1\%), relatively new tenure / $\leq 6$ years (53.5\%) and having experience of handling KEK (81.7\%). There was a correlation between health facilities 
$(p=0.001)$, co-workers support $(p=0.016)$, community support $(p=0.001)$, leader's support $(p=0.0001)$ and the performance of midwives in the early detection of pregnant women's KEK. Factors that influence simultaneously on the performance were health facilities $(p=0.000$; $\operatorname{Exp}(B)=25.395)$, the leader's support $(p=$ $0.00 ; \operatorname{Exp}(B)=10.278)$.

It was recommended that all related instances (Public Health Centers and Regency Health Offices) provide complete and adequate health facilities in order to improve the health staffs' performance in their service.

Keywords : Midwives, Performance, Early Detection and Treatment of Pregnant Women's KEK

Bibliography : 14 (1990-2011)

\section{Pendahuluan}

Program kesehatan ibu dan anak merupakan salah satu prioritas utama pembangunan kesehatan Indonesia untuk menurunkan kematian dan kejadian sakit di kalangan ibu, bayi dan anak. Angka kematian ibu dan bayi di Indonesia masih lebih tinggi dibandingkan dengan negara ASEAN yang lain, dan upaya penanggulangannya cukup rumit. Angka kematian ibu (AKI) dan angka kematian bayi (AKB) masih merupakan masalah kesehatan masyarakat di Indonesia. ${ }^{1}$

Angka Kematian Ibu (AKI) Provinsi Jawa Tengah tahun 2010 sebesar 117,02/100.000 kelahiran hidup, dan belum memenuhi target dalam MDGs tahun 2015 sebesar 102/100.000 kelahiran hidup dan AKB tahun 2009 sebesar 10,25/1.000 kelahiran hidup, sudah melampaui target MDGs ke-4 tahun 2015 yaitu 17/1.000 kelahiran hidup. ${ }^{4}$

Berdasarkan indikator dampak program Kesehatan Ibu dan Anak (KIA) di Kabupaten Grobogan selama periode tahun 2011-2013 diketahui ada kecenderungan meningkatnya kasus kematian ibu. Absolut kematian ibu tahun 2011 sebanyak 26 kasus (AKI 114,03/100.000 KH), tahun 2012 meningkat menjadi 34 kasus (AKI $151,15 / 100.000 \mathrm{KH})$, dan tahun 2013 menurun menjadi 22 kasus (AKI $102,03 / 100.000 \mathrm{KH}) .^{5}$

Penyebab kematian ibu salah satunya adalah perdarahan yang dipicu oleh anemia yang dialami ibu selama masa kehamilan. Sedangkan AKB tahun 2011 sebesar 194 kasus, terjadi kenaikan pada tahun 2012 sebesar 240 dan kembali turun pada tahun 2013 sebesar 166 kasus. ${ }^{5}$ Salah satu penyebab AKB adalah BBLR dengan sejumlah 72 kasus pada tahun 2011, kemudian naik pada tahun 2012 sejumlah 99 kasus, dan turun kembali tahun 2013 sejumlah 77 kasus. BBLR terjadi karena pada masa kehamilan ibu mengalami KEK. $^{5}$

Ibu KEK adalah ibu yang ukuran LiLA nya $<23,5 \mathrm{~cm} .{ }^{9}$ Faktor risiko lain dari KEK dengan lingkar lengan atas kurang dari 23,5 $\mathrm{cm}$ pada pemeriksaan $\mathrm{K} 1$, atau penambahan berat badan $<9 \mathrm{~kg}$ selama masa kehamilan, anemia dengan Hemoglobin $<11$ g/dl. ${ }^{7}$ Jumlah ibu hamil KEK di Kabupaten Grobogan tahun 2011 sebanyak 1540 kasus $(15,75 \%)$, tahun 2012 sebanyak 1305 kasus $(16,00 \%)$, dan tahun 2013 sebanyak 1368 kasus $(15,73 \%) .{ }^{5}$

Berdasarkan hasil studi pendahuluan yang dilakukan peneliti tentang deteksi dini pada ibu hamil KEK oleh bidan di desa dalam bentuk wawancara pada 10 bidan desa, diperoleh informasi sebagai berikut: sebanyak 5 bidan menyatakan ketika pengukuran LiLA pada kunjungan pertama kehamilan (K1) tidak dilakukan, namun hanya dilihat pada ibu hamil, lengan atasnya kecil atau tidak. Sebagian besar bidan melakukan penimbangan berat badan pada kunjungan pertama kehamilan (K1) dan pemeriksaan selanjutnya, namun pada proses penimbangannya ibu hamil menimbang sendiri dan hasilnya disampaikan pada bidan.

Sebanyak 5 bidan menyatakan pada kunjungan pertama kehamilan (K1) tidak dilakukan pengukuran tinggi badan, namun hanya menanyakannya kepada ibu hamil atau tidak ditanyakan sama sekali. Sebanyak 3 bidan menyatakan pada kunjungan pertama kehamilan (K1) tidak dilakukan pemeriksaan Hb. Sebagian besar bidan menyatakan melaporkan jika ada kejadian KEK, tetapi tidak dilakukan upaya tindaklanjut penanganan KEK pada ibu hamil tersebut. Sebagian besar bidan menyatakan tidak ada insentif untuk melakukan kegiatan deteksi dini pada ibu hamil KEK. 
Selain itu, peneliti melakukan wawancara pada 3 ibu hamil yang mengalami KEK diperoleh informasi sebagai berikut: sebanyak 2 ibu mengatakan bahwa tidak diukur tinggi badannya oleh bidan pada kunjungan K1. Sebanyak 2 ibu hamil menyatakan melakukan pengukuran timbang berat badan sendiri ketika pemeriksaan kehamilan dan hasilnya diinformasikan ke bidan. Sebanyak 2 ibu hamil menyatakan bahwa bidan tidak mengukur LiLA pada kunjungan K1. Sebanyak 2 ibu hamil menyatakan bahwa bidan tidak memeriksa $\mathrm{Hb}$ pada kunjungan K1. Berdasarkan uraian di atas maka peneliti ingin melakukan penelitian dengan judul "Analisis Hubungan Faktor Internal dan Eksternal dengan Kinerja Bidan Desa dalam Deteksi Dini dan Penanganan Ibu Hamil Kekurangan Energi Kronik (KEK) di Kabupaten Grobogan 2015.”

\section{Metode Penelitian}

Jenis penelitian observasional analitik dengan pendekatan Cross Sectional. Populasi penelitian adalah bidan bidan desa di Kabupaten Grobogan sebanyak 243. Cara pengambilan sampel dengan tehnik Stratified Random Samplin sebanyak 71. Variabel bebas terdiri dari pengetahuan, ketrampilan, sikap, fasilitas kesehatan, dukungan rekan kerja, dukungan masyarakat, dan dukungan pimpinan. Variabel terikat kinerja bidan desa dalam deteksi dini dan penanganan ibu hamil KEK. Pengumpulan data menggunakan kuesioner dan lembar cheklist. Analisis data menggunakan analisis univariat (distribusi frekuensi), analisis bivariat (uji Chi Square) dan analisis multivariate dengan Regresi Logistik.

\section{Hasil}

Umur responden 20-35 tahun atau dewasa muda $(76,1 \%)$, masa kerja baru $(53,5 \%)$ dan pernah melakukan penanganan KEK $(81,7 \%)$. Kinerja bidan baik $(63,4 \%)$, pendidikan baik $(67 \%)$, pengetahuan baik $(83,1 \%)$, trampil $(76,1 \%)$, sikap baik $(50,7 \%)$, fasilitas kesehatan baik (74,6\%), dukungan rekan kerja baik $(78,9 \%)$, dukungan masyarakat baik (70,4\%), dan dukungan pimpinan baik $(69 \%)$. Distribusi frekuensi semua variabel (kinerja, pendidikan, pengetahuan, sikap, ketrampilan, fasilitas kesehatan, dukungan rekan kerja, dukungan masyarakat dan dukungan pimpinan) akan disajikan dalam Diagram 1

\section{Deskripsi Variabel Kinerja}

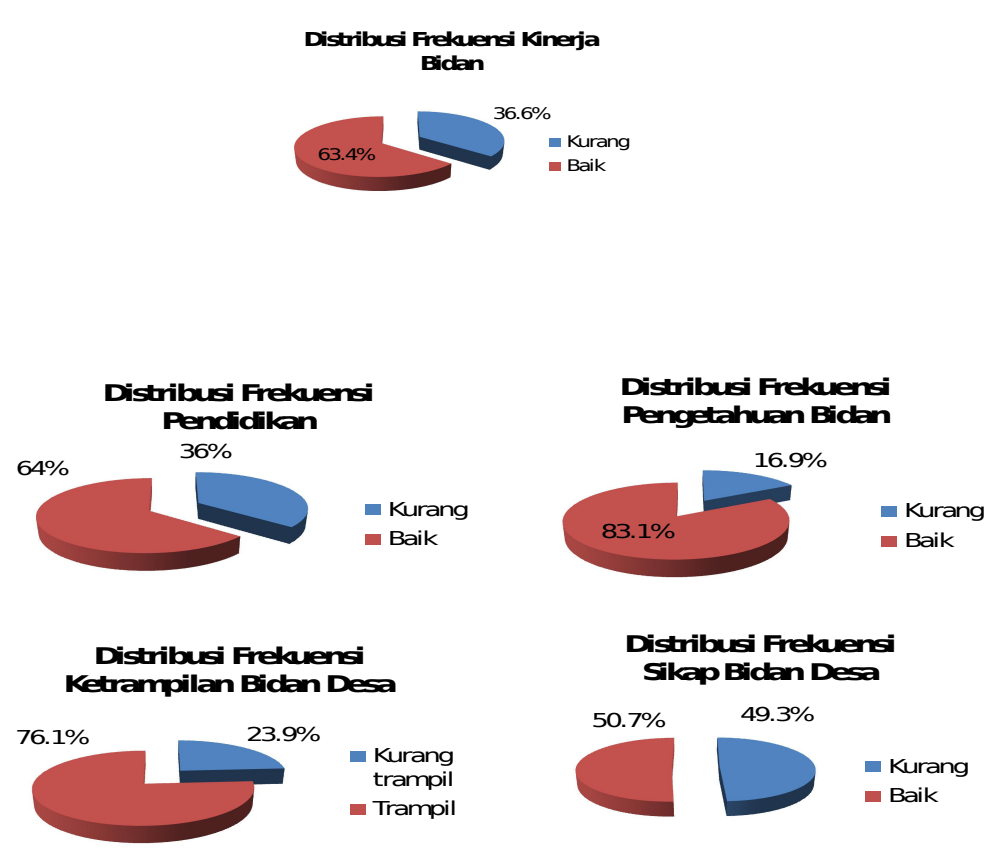

Diagram 1 : Kategori kinerja, pengetahuan, ketrampilan, sikap. 
Hasil distribusi frekuensi kinerja jawaban responden $1,4 \%$ bidan menjelaskan penanganan kejadian KEK pada ibu hamil, responden $11,3 \%$ yaitu bidan memberikan PMT bagi ibu hamil KEK setiap sebulan sekali dan responden rutin melakukan kunjungan rumah pada setiap ibu hamil KEK di wilayahnya, $18,3 \%$ responden memberikan PMT bagi ibu hamil KEK setiap sebulan sekali.

Hasil distribusi frekuensi pengetahuan jawaban $11,3 \%$ responden melakukan deteksi dini KEK dapat dilakukan dengan pengukuran LILA, 23,9\% reponden Ibu hamil KEK harus dirujuk ke puskesmas atau sarana pelayanan kesehatan lain, 35,2\% responden risiko ibu hamil KEK dapat diketahui dari keadaan seseorang sejak remaja.

Hasil distribusi frekuensi ketrampilan jawaban 2,8\% responden memastikan ibu rileks saat memasang LILA sehingga otot lengan ibu tidak tegang atau kencang, mencatat hasil pengukuran LILA dan penimbangan $\mathrm{BB}$ ibu hamil pada buku KIA, membaca skala hasil $\mathrm{BB}$ ibu hamil dari arah depan pasien, memberikan KIE pada ibu hamil dengan KEK.

Hasil distribusi frekuensi ketrampilan jawaban $1,4 \%$ responden melakukan kegiatan deteksi dini ibu hamil KEK terutama pada setiap ibu hamil merupakan pekerjaan yang baik bagi saya, setiap temuan kasus ibu hamil KEK harus segera saya rujuk ke puskesmas atau sarana pelayanan kesehatan lain dan saya melakukan penanganan segera KEK dengan pemberian PMT pada ibu hamil.
Hasil distribusi frekuensi fasilitas kesehatan jawaban 5,6\% responden mengatakan pengukuran tinggi badan tidak ada, $15,5 \%$ responden mengatakan tablet $\mathrm{Fe}$ tidak ada. Hasil distribusi frekuensi dukungan rekan kerja jawaban $1,4 \%$ responden mengatakan rekan kerja bersedia meminjamkan alat untuk deteksi dini KEK tanpa suatu imbalan apapun, rekan kerja selalui memotivasi saya dalam mendeteksi dini ibu hamil KEK, rekan kerja membantu dalam pembuatan laporan bulanan untuk Puskesmas.

Hasil distribusi frekuensi dukungan rekan kerja jawaban $1,4 \%$ responden mengatakan kader atau Ibu PKK menganggap bahwa kejadian KEK pada ibu hamil merupakan peristiwa kehamilan yang tidak wajar, 4,2\% responden mengatakan kader atau Ibu PKK dapat bekerjasama saat pelaksanaan deteksi ibu hamil KEK. Hasil distribusi frekuensi dukungan rekan kerja jawaban 4,2\% responden mengatakan bidan Koordinator memberikan pengarahan tentang tugas dan fungsi pelaksana deteksi dini bumil KEK, bidan Koordinator memberikan solusi terhadap kesulitan yang dihadapi petugas deteksi dini bumil KEK.

Hasil Analisis Bivariat dengan menggunakan uji Chi Square didapatkan hasil tidak adanya hubungan antara faktor internal (pendidikan, pengetahuan, ketrampilan, sikap) dengan kinerja dan adanya hubungan antara faktor eksternal (fasilitas kesehatan, dukungan rekan kerja, dukungan masyarakat, dukungan pimpinan) dengan kinerja.
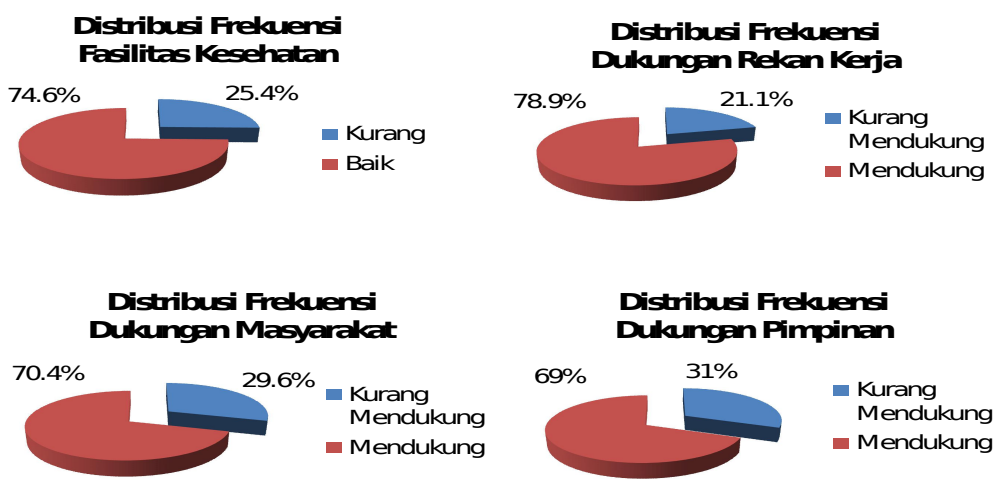

Diagram 2 : Kategori fasilitas kesehatan, dukungan rekan kerja, dukungan masyarakat, dukungan pimpinan. 


\section{Analisis Bivariat \\ Falktor Internal}

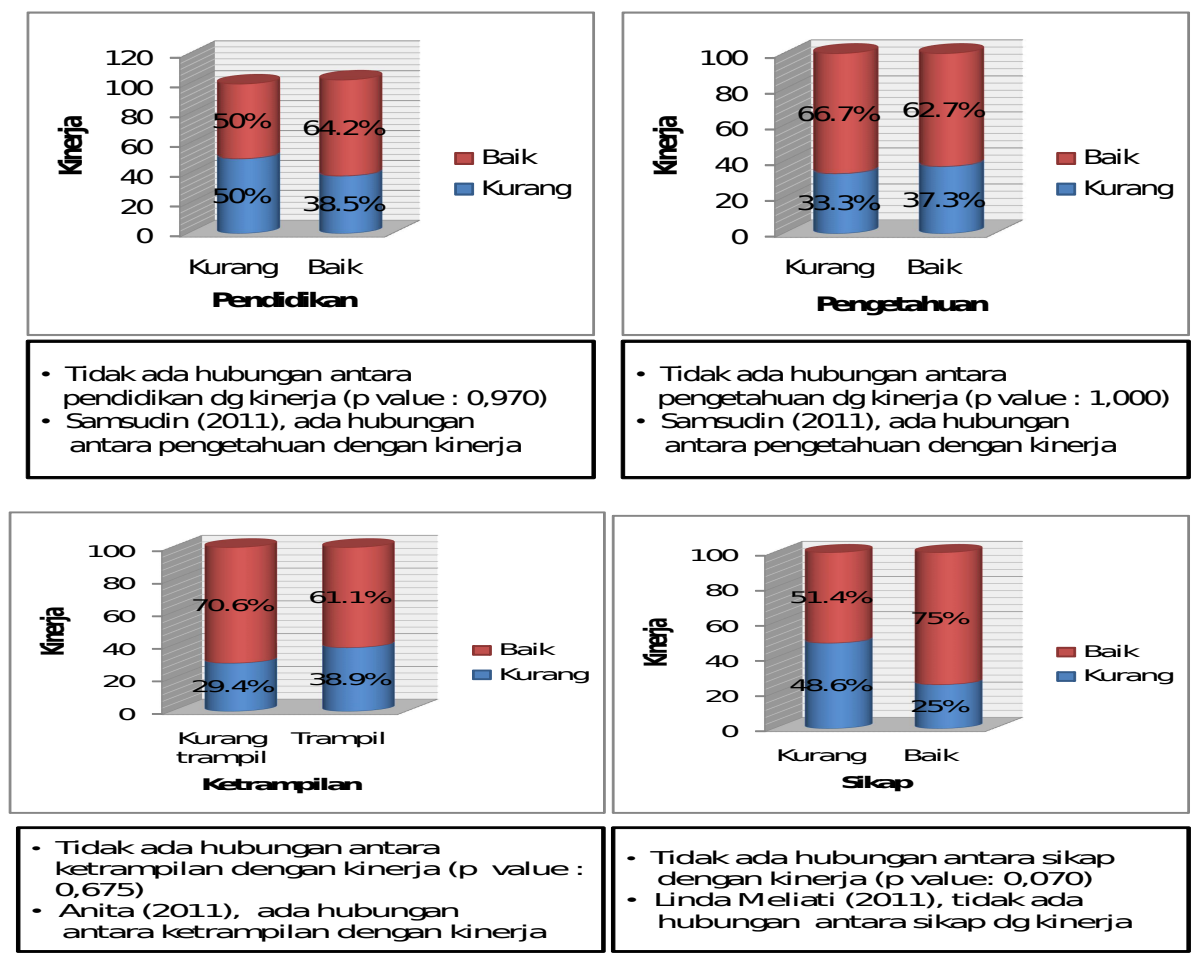

Gambar 1: Analisis hubungan faktor internal dengan kinerja bidan desa dalam deteksi dini dan penanganan ibu hamil KEK.

Gambar 1 menunjukkan bahwa responden bidan dengan kinerja baik responden bidan yang kinerjanya baik diketahui yang mempunyai pendidikannya kurang persentasenya sedikit lebih kecil (50\%) dibandingkan dengan bidan yang mempunyai pendidikan baik $(64,2 \%)$.

Responden bidan yang kinerjanya baik diketahui yang mempunyai pengetahuan baik persentasenya sedikit lebih kecil (62,7\%) dibandingkan dengan bidan yang mempunyai pengetahuan kurang $(66,7 \%)$.

Responden bidan dengan kinerja baik diketahui yang mempunyai ketrampilan baik persentasenya sedikit lebih kecil $(61,1 \%)$ dibandingkan dengan bidan dengan ketrampilan kurang (70,6\%).

Responden bidan yang kinerjanya baik diketahui yang memiliki sikap baik persentasenya lebih besar (75\%) dibandingkan dengan bidan dengan sikap kurang mendukung $(51,4 \%)$. Sedangkan pada kelompok responden bidan dengan kinerja kurang yang memiliki sikap baik persentasenya lebih sedikit (25\%) dibandingkan dengan sikap kurang baik (48,6\%). Gambar 2 menunjukkan bahwa diketahui yang memiliki fasilitas kesehatan baik ternyata lebih besar persentasenya $(79,2 \%)$ dibandingkan bidan dengan fasilitas kesehatan kurang (16,7\%). Sedangkan pada kelompok bidan dengan kinerja kurang, yang memiliki fasilitas kesehatan baik ternyata lebih sedikit persentasenya (20,8\%) dibandingkan dengan bidan yang mempunyai fasilitas kesehatan kurang $(83,3 \%)$.

Responden bidan dengan kinerja baik ternyata yang memiliki dukungan rekan kerja baik lebih besar persentasenya $(71,4 \%)$ dibandingkan dengan persentase bidan yang mempunyai dukungan rekan kerja kurang baik $(33,3 \%)$. Sedangkan pada kelompok responden bidan dengan kinerja kurang, persentase yang memiliki dukungan rekan kerja baik lebih sedikit $(28,6 \%)$ dibandingkan bidan dengan dukungan rekan kerja kurang baik $(66,7 \%)$.

Responden bidan dengan kinerja baik ternyata yang memiliki dukungan masyarakat baik persentasenya lebih banyak (72\%) dibandingkan dengan persentase bidan yang mempunyai dukungan masyarakat kurang 
(42,9\%). Sedangkan pada kelompok responden bidan dengan kinerja kurang, yang memiliki dukungan masyarakat baik persentasenya lebih kecil (28\%) dibandingkan persentase bidan dengan dukungan masyarakat kurang $(57,1 \%)$.

Responden bidan dengan kinerja baik ternyata persentase yang memiliki dukungan pimpinan yang baik lebih besar $(77,6 \%)$ dibandingkan persentase bidan dengan dukungan pimpinan yang kurang $(31,8 \%)$. Sedangkan pada kelompok bidan dengan kinerja kurang, yang memiliki dukungan pimpinan yang baik persentasenya juga lebih sedikit $(22,4 \%)$ bila dibandingkan dengan bidan yang dukungan pimpinannya kurang $(68,2 \%)$

Hasil Analisis Multivariat dilakukan dengan uji Regresi Logistik dengan metode ENTER, menunjukkan bahwa fasilitas kesehatan $(\operatorname{Exp}(B)=25,395$; nilai $\mathrm{p}=0,000)$ dan dukungan pimpinan $(\operatorname{Exp}(\mathrm{B})=10,278$; nilai $\mathrm{p}=0,001)$ berpengaruh terhadap kinerja bidan desa dalam deteksi dini dan penanganan ibu hamil KEK dapat dilihat pada tabel 1.

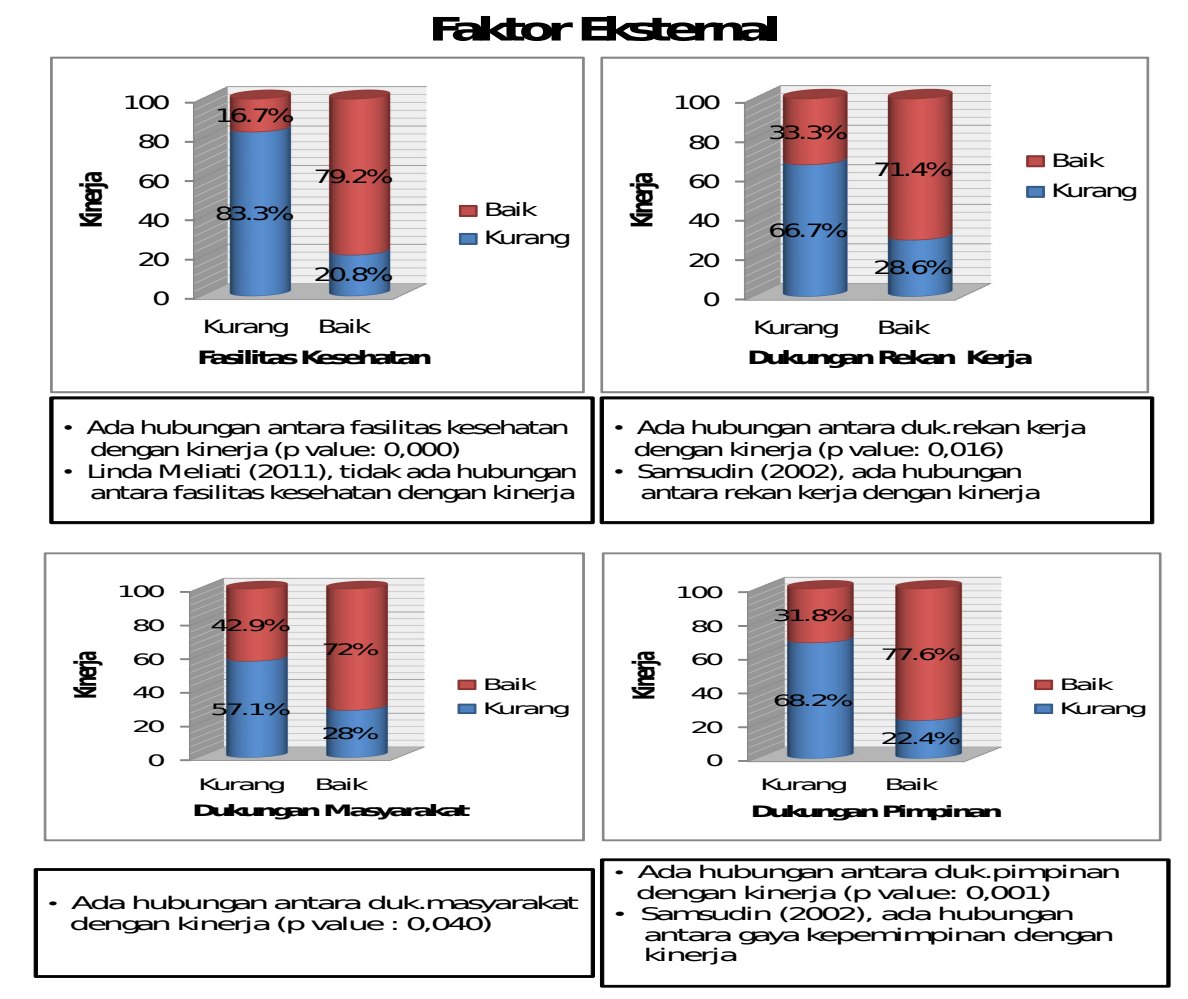

Gambar 2: Hubungan antara faktor eksternal dengan kinerja bidan desa dalam deteksi dini dan penanganan ibu hamil KEK.

Tabel 1: Hasil Analisis Multivariat

\begin{tabular}{lcccccc}
\hline Variabel & B & S.E. & Wald & df & Nilai $\mathrm{p}$ & $\operatorname{Exp}(\mathrm{B})$ \\
\hline Fasilitas kesehatan & 3.235 & .817 & 15.669 & 1 & .000 & 25.395 \\
\hline Dukungan pimpinan & 2.330 & .716 & 10.599 & 1 & .001 & 10.278 \\
\hline
\end{tabular}

Nagelkerke R Square: 0,535

\section{Pembahasan}

Pendidikan mempunyai nilai $\mathrm{p}=0,970$. Pendidikan dianggap memiliki peranan penting dalam menentukan kualitas manusia melalui pendidikan. Manusia dianggap akan memperoleh pengetahuan dan dengan pengetahuan manusia akan dapat membangun keberadaan hidupnya dengan lebih baik. Implikasinya semakin tinggi tingkat pendidikan hidup manusia akan semakin 
berkualitas, dimana semakin tinggi pendidikan maka seseorang akan semakin mudah untuk menerima hal-hal yang baru dan mudah menyesuaikan diri dengan hal-hal baru tersebut, tetapi tidak menutup kemungkinan bahwa pendidikan rendah punya pengetahuan dan sikap yang lebih baik. ${ }^{15}$

Pengetahuan mempunyai nilai $p=$ 1,000. Pengetahuan dipengaruhi oleh faktor pendidikan formal. Pengetahuan sangat erat hubungannya dengan pendidikan, dimana diharapkan bahwa dengan pendidikan yang tinggi maka orang tersebut akan semakin luas pula pengetahuannya. Akan tetapi perlu ditekankan, bukan berarti seseorang yang berpendidikan rendah mutlak berpengetahuan rendah pula. ${ }^{12}$

Ketrampilan mempunyai nilai $\mathrm{p}=$ 0,675 . Ketrampilan adalah kecakapan yang spesifik yang dimiliki seseorang berkaitan/ berhubungan dengan penyelesaian tugas secara cepat dan tepat. ${ }^{16}$ Ketrampilan merupakan kecakapan yang berkaitan dengan tugas yang dimiliki dan digunakan seseorang pada waktu yang tepat. ${ }^{11}$

Sikap mempunyai nilai $\mathrm{p}=0,070$. Sikap atau attitude adalah respon tertutup seseorang terhadap stimulus atau objek tertentu, yang melibatkan faktor pendapat atau emosi yang bersangkutan. ${ }^{10}$

Fasilitas kesehatan mempunyai nilai $\mathrm{p}=0,000$. Fungsi alat adalah untuk meningkatkan kinerja karyawan dalam proses pelaksanaan pekerjaan. Salah satu faktor pendukung yang tidak boleh dilupakan dalam pelayanan adalah faktor sarana atau alat dalam pelaksanaan tugas pelayanan. Sarana pelayanan yang dimaksud disini adalah segala jenis peralatan, perlengkapan kerja dan fasilitas lain yang berfungsi sebagai alat utama/pembantu dalam pelaksanaan pekerjaan. ${ }^{13}$

Dukungan rekan kerja mempunyai nilai $p=0,016$. Rekan kerja bidan desa adalah karyawan yang berhubungan langsung maupun tidak langsung dalam pelaksanaan tugas bidan desa. ${ }^{13}$ Mengingat pentingnya hubungan antar karyawan maka perlu diusahakan untuk meniadakan konflik diantara para petugas serta menghilangkan rasa curiga dan sikap sinis baik yang rasional maupun emosinal untuk meningkatkan tercapainya tujuan organisasi. ${ }^{13}$

Dukungan masyarakat mempunyai nilai $p=0,040(p<0,05)$. Dukungan diartikan sebagai suatu bentuk dari bantuan yang diberikan seseorang kepada orang lain. Sedangkan dukungan sosial berfokus pada sifat interaksi yang berlangsung dalam berbagai hubungan sosial sebagaimana dievaluasi oleh individu. Dukungan sosial dianggap melemahkan dampak stress dan secara langsung memperoleh kesehatan mental individu dan keluarga. ${ }^{13}$

Dukungan pimpinan mempunyai nilai $p=0,001$. Hubungan antar pribadi dalam organisasi bermanfaat agar pimpinan dapat memecahkan masalah bersama karyawan baik masalah individu maupun masalah umum organisasi sehingga dapat meningkatkan semangat dan produktifitas kerja. ${ }^{13}$

Dari semua variabel bebas yang di analisis secara bersama - sama diketahui variabel fasilitas kesehatan dengan nilai $\operatorname{Exp}(B)$ dapat dijelaskan bahwa setiap peningkatan fasilitas kesehatan sebesar 1 poin, cenderung dapat meningkatkan kinerja bidan desa dalam deteksi dini dan penanganan KEK ibu hamil sebesar 25,395 kali. Selanjutnya diketahui bahwa adanya peningkatan dukungan pimpinan 1 poin, ada kecenderungan terjadinya peningkatan kinerja bidan desa dalam deteksi dini dan penanganan KEK sebesar 10,278 kali. Variabel fasilitas kesehatan dan dukungan pimpinan secara berama-sama membawa pengaruh pada kinerja bidan desa dalam deteksi deteksi dini dan penanganan KEK sebesar 53,5\%.

\section{Kesimpulan}

Faktor yang berpengaruh secara bersama - sama terhadap kinerja bidan desa dalam deteksi dini dan penanganan ibu hamil KEK adalah fasilitas kesehatan dan dukungan pimpinan.

\section{Daftar Pustaka}

1. Depkes RI. Standar Pelayanan Kebidanan. Jakarta: 2002

2. Dinas Kesehatan Provinsi Jawa Tengah. Profil Kesehatan Indonesia 2009. Semarang: 2010 
3. Dinas Kesehatan Kabupaten Grobogan. Profil Kesehatan Kabupaten Grobogan 2010. Grobogan: 2011

4. RI. Pedoman Perencanaan Program. Gerakan Sadar Gizi dalam Rangka Seribu Hari Pertama Kehidupan (1000 HPK). Jakarta: 2012

5. Depkes RI. Supervisi Suportif. Jakarta: Depkes RI; 2007

6. Ikatan Bidan Indonesia. Standar Pelayanan Kebidanan. Jakarta: 2006

7. Muchlas, M. Perilaku Organisasi II. Program Pendidikan Pasca Sarjana Magister Manajeman Rumah Sakit. Yogyakarta: UGM; 1997

8. Gibson, James L, John M. Ivancevich, James H. Donnelly, Jr, Organizatio :Behavior, Structure, Processes, $7^{\text {th }}$ ed. Irwin; Boston; 1996

9. Hendi, Sahya. Khaerul Umam. Perilaku Organisasi. Penerbit CV. Bandung: Pustaka Setia; 2010

10. Stoner, James, et. Al. Management. Sixth Edition. Jakarta: PT. Prenhallindo; 1990

11. Robbins, S.P. Perilaku Organisasi. Jakarta: PT Prenhalindo; 1996

12. Notoatmojo, S. Promosi Kesehatan dan Ilmu Perilaku. Jakarta: Penerbit PT Rineka Cipta; 2007

13. Handoko, H. Manajemen Personalia Dan Sumber Daya Manusia. Yogyakarta: BPFE; 1995

14. Ikatan Bidan Indonesia. Kepmenkes RI No. 369/Menkes/SK/III/2007. Jakarta: IBI; 2007

15. Suwarto, FX. Perilaku Keorganisasian. Yogyakarta: Penerbit Universitas Atma Jaya; 1999

16. Azwar, A. Pengantar Administrasi Kesehatan. Jakarta: Binarupa Aksara; 1996 